PROBLEMS

OF EDUCATION

IN THE $21^{\text {st }}$ CENTURY

Vol. 76, No. 6, 2018

762

RECOGNITION OF INDICATORS FOR THE DEVELOPMENT OF THE COGNITIVE DIMENSIONS IN TERTIARY EDUCATION

\author{
Kateřina Berková, Jana Borůvková, Lenka Lízalová \\ College of Polytechnics Jihlava, Czech Republic \\ E-mail: katerina.berkova@vspj.cz; boruvkova@vspj.cz; lizalova@vspj.cz
}

\begin{abstract}
The aim of the research was to find out what factors influence the development of cognitive dimensions in college students. The following factors were considered: field of study, academic achievement in a selected economic subject and abstract visual intellectual level. The reason for doing this research was to increase the quality of teaching economic subjects across bachelor study fields in the conditions of a practically oriented College of Polytechnics, Jihlava in the Czech Republic. Two fields of study were selected - the economic field - Finance and Management ( $N=52$ students) and the technical field-Applied Computer Science ( $N=30$ students). Study plans of both fields included the subject Corporate Economy in the first term of studies. Methodological research was based on the theory of problem-based learning. It was built on a test method that was used to gain data to identify the context of variables with the development of cognitive dimensions in the context of an internationally recognized framework for evaluating the success - the Bloom's Taxonomy. Two tests were used to collect the data: (a) a test measuring the abstract visual intellectual level; (b) a non-standardized test to measure students' achievement in the six cognitive dimensions of the Bloom's Taxonomy. The initial knowledge of students was comparable. The data were analyzed by factor analysis, followed by the Spearman and Pearson correlation coefficients. Cognitive dimensions could be grouped into two factors. Factor 1 - Application-Evaluation Dimension that was explained by the dimensions of Knowledge, Application, Evaluation; Factor 2 - Analytical Dimension that was explained by the dimensions of Comprehension, Analysis, Synthesis. The results showed that an individual did not have to be competent in the whole complexity of the Bloom's Taxonomy. The development of cognitive dimensions correlated with the field of study, the economic field was correlated with factor 2 and the technical field with factor 1. The development of cognitive dimensions did not correlate with the abstract-visual intellectual level. Factor 2 weakly negatively correlated with academic achievement in the subject Corporate Economy. This means that students who were successful in developing lower-order cognitive dimensions had a weak analytical orientation in the economic area, and vice versa. The results brought by the research will help improve teaching of economic subjects across the two disciplines, especially with regard to the innovation of learning and teaching strategies with a positive impact on the desired cognitive development of students.
\end{abstract}

Keywords: cognitive dimensions, problem-based learning, logical reasoning, tertiary education.

\title{
Introduction
}

Economic education today faces a large number of challenges that are closely related to finding suitable ways to develop desirable students competencies such as competence to solve problems, work with information, analyze the problem, find solutions, have creative thinking ability, etc. In an international context, education is focused on constructivist learning environment (Banchi \& Bell, 2008; Cetin-Dindar, 2012). This constructivist learning model includes teaching methods with an emphasis on learning experience. Case studies, reearch and 
the problem based learning are dominant in it. They are used to encourage thinking about solutions of practical problems and to develop competencies mentioned above. Constructivist learning environment is a good way not only to attract students' interest in education in economic subjects (Steelová, Meredith, Temple, \& Walter, 1997), but also to develop the professional profile of students (Siew \& Chin, 2018; Škoda, Doulík, Bílek, \& Šimonová, 2016). At the same time constructivist learning environment suppports gaining of practical experience, develops analytical skills, critical thinking, but also strengthens social competence, improves students' learning strategies (Broks, 2016; Koenig, 2011). On the other hand, the focus of Czech education is more shifted to lower levels of Bloom's Taxonomy of educational objectives (Anderson \& Kratwohl, 2001; Bloom, 1956;), which means that the development of higher thinking processes (mentioned above) in the Czech conditions is receding into the background (Barrett \& Moore, 2012; Berková, Krejčová, Králová, Krpálek, Krpálková Krelová, \& Kolářová, 2018).

In the international environment, the demands on economic education have been increasing. At a lower age (15 years old) students should already have a certain level of economic knowledge. In particular, they should be able to analyze and make decisions in every day financial situations (OECD, 2014). According to the international comparison of financial literacy of students at the age of 15 at the level of all the world's continent (Programme for International Student Assessment) it was found out that Czech students managed to analyze and make decisions in every day financial situations, but they were not able to analyze complex, not very clear financial products and financial situations lasting a long period of time (OECD, 2014). Czech students ranked among students with above-average results (other successful states were Shanghai, Belgium, Estonia, Australia, New Zealand). In 2017 the OECD published further results of international comparison of students. Czech students achieved almost average OECD performance, which was set at 500 points. The total number of students in the Czech Republic was at 499 points (OECD, 2017). The performance of Czech students has been oscillating around the OECD average.

In terms of secondary education, international research was carried out (Zoller, 2015), based on the presumption that school assessment and, in particular, academic achievement of students might not fully represent their real economic abilities, since at secondary schools all cognitive levels under the Bloom's Taxonomy (Bloom, 1956) - an internationally recognized framework for the assessment of cognitive abilities - were not included. Research done in the international environment (Zoller, 2015) and the Czech environment (Berková \& Krpálek, 2017; Berková, Krejčová, Králová, Krpálek, Krpálková, Králová, \& Kolářová, 2018) proved that there was a weak relation between academic achievement which usually reflected the lowerorder cognitive levels and the real cognitive abilities of students that might not correspond to those needed at school. This relation between academic achievement and achievement under Bloom's Taxonomy of Cognitive Goals was also demonstrated in the academic environment by Kiliyanni and Sivaraman (2016) and further confirmed in the USA(Little, Miyashita, Karasawa, Mashima, Oettingen, Azuma, \& Baltes, 2003). It demonstrates that students with good study results not only at secondary school but also in college may not have the required competencies such as critical, creative, analytical thinking, problem solving ability to identify a problem, etc., and on the contrary students who have these desirable abilities may not have good study results. Additionally, the development of cognitive levels may also be conditioned by a study field (Buli $\&$ Yesuf, 2015). However, the question remains: What other factors influence the development of cognitive dimensions according to an internationally recognized framework for assessment of cognitive abilities - Bloom's Taxonomy? (Bloom, 1956)

\section{Aim of Research}

The aim of this research was to look into factors relating to the development of cognitive process dimensions according to the Bloom's Taxonomy (Bloom, 1956) in students of practically

\begin{tabular}{|l} 
PROBLEMS \\
OF EDUCATION \\
IN THE 21 $1^{\text {st }}$ CENTURY \\
Vol. 76, No. 6, 2018
\end{tabular}

763 
Kateřina BERKOVÁ, Jana BORU゚VKOVÁ, Lenka LÍZALOVÁ. Recognition of indicators for the development of the cognitive dimensions in tertiary education

\section{PROBLEMS \\ OF EDUCATION \\ IN THE $21^{\text {st }}$ CENTURY Vol. 76, No. 6, 2018 \\ 764}

oriented college in economic subjects. The development of cognitive levels was researched in an interdisciplinary way, in the economic and technical fields as well as from the point of view of the abstract visual intellectual level of students and the academic achievement in the subject of Corporate Economy. The subject Corporate Economy was chosen because of two reasons: it was a common subject for both study fields and that the research was primarily focused on improving the quality of teaching economic subjects across the two fields. At the same time, it was essential to find out differences in students' logical thinking of both fields of study in an economic subject. Because of the representation of cognitive dimensions of the lower and higher order, it was desirable to focus on the problem solving process (mentioned eg by Broks, 2016; Dasgupta \& David, 1994). The original Bloom's Taxonomy was chosen in the light of the following facts: (a) the difficulty of the subject Corporate Economy, which reflected only the basic level of the subject matter in terms of educational content; (b) students from both study fields who passed the subject had no economic entrance knowledge. Therefore, it was desirable to choose a simpler - one-dimensional taxonomy of cognitive dimensions.

\section{Research Hypotheses}

Following research hypotheses were verified:

1. The field of study influences the development of cognitive dimensions according to Bloom's Taxonomy in Corporate Economy.

2. Academic achievement in Corporate Economy correlates with students' performance in cognitive dimensions according to Bloom's Taxonomy.

3. Abstract-visual intelligence correlates with the performance of students in cognitive dimensions according to Bloom's Taxonomy in Corporate Economy.

\section{Theoretical Foundation}

In the historical context, the Bloom's Taxonomy of Cognitive Objectives is considered to be an internationally recognized framework for evaluating the achievement of students in education (Bloom, 1956). The taxonomy distinguishes six cognitive levels: Knowledge, Comprehension, Application, Analysis, Synthesis, Evaluation without a reference to a knowledge domain which is used by Anderson and Krathwohl (2001) after the revision of the taxonomy. At the same time, this taxonomy categorizes the cognitive dimensions into: (a) the Dimension of the Lower Order (Knowledge, Comprehension, Application), and (b) the Higher Order Dimension (Analysis, Synthesis, Evaluation) (Crowe, Dirks, \& Wenderoth, 2008; Salomon, 1996). The original taxonomy has been revised to the current, recognized and used form (Anderson \& Krathwohl, 2001). The revised Bloom's Taxonomy has proven to be a useful tool for deeper exploration of the alignment of learning strategies (Crowe, Dirks \& Wenderoth, 2008), learning goals and assessment (Allen \& Tanner, 2002), which support the interest of teachers to include more complex cognitive tasks across all educational levels and disciplines. In this study, the researchers deal with the original taxonomy (Bloom, 1956), since its arrangement of cognitive dimensions more closely corresponds to the research goal.

Cognitive dimensions relate to the process of thinking that can be defined as: Learning is any relatively permanent change in actual or potential behaviour of an individual that occurs as a result of experience. Cognitive approaches to learning focus mainly on the changes in thought that are part of learning (Sternberg \& Williams, 2010). The thinking process also includes problem solving which can be defined by Plamínek (2008) using this algorithm: (a) defining the problem, (b) analyzing the problem = formulating hypotheses, (c) generating possible solutions, (d) sorting possible solutions, (e) assessing solutions and heading to phase (f) decision making and implementation. Critical thinking is important for problem solving through economic educational content as it guarantees effective knowledge acquisition (Siew 
Kateřina BERKOVÁ, Jana BORŮVKOVÁ, Lenka LÍZALOVÁ. Recognition of indicators for the development of the cognitive dimensions in tertiary education

\& Chin, 2018). Indonesian teacher Subroto (2015), who explored cognitive approaches to the development of critical thinking in students of economic disciplines, confirmed in his research that higher professional profiling of students could be obtained by developing of this type of thinking. It has also been confirmed by the complex research (Zoller, 2015) that the revision of educational content is a precondition for successful development of higher-order cognitive dimensions.

In general, for developing thinking the economic theories are the main pillar in the system of logical thinking. This can be demonstrated by the example of sociological sciences which come out of analogies of economic sciences (Mäki, 1992). Similarly, teaching theory uses the interpretation of methods of economic science. Economic sciences are the carriers of rational behavior and thinking (Dasgupta \& David, 1994). The core of the approach to economic science was described by American pragmatic philosopher Charles Sanders Peirce (1967) in his Note on the Theory of the Economy of Research. Peirce (1967) stated that economic science used an analytical apparatus derived from economic theory. This apparatus then used methods of economic science and was applicable to other disciplines (Loužek, 2016, p. 496).

Among methods that are based on Corporate Economy and are the core of the development of thinking, Jureček (2003); Sternberg and Williams (2010) mention the following ones: (a) abstraction that enables to distinguish between essential and non-essential and the subject of research to make accessible to analysis; (b) analysis enabling the complex to be taken apart into manageable parts; (c) synthesis putting together phenomena, processes from taken apart parts into more integral unity; (d) inductive reasoning ,, is the process of drawing reasonable general conclusions from specific facts or observations. In other words, it is a process going from the specific to the general. In induction, it is not possible to have logical certainty. There is always the chance that the next observation you make will disconfirm what all the previous observations have confirmed" (Sternberg \& Williams, 2010, p. 317); (e) deductive reasoning „is the process of drawing specific, logically valid conclusions from one or more general premises. In other words, it is a process of going from the general to the specific. By its nature, deductive reasoning leads to conclusions that are logically certain " (Sternberg \& Williams, 2010, p. 317).

It is common that academic achievement of students is often not viewed by using internationally recognized assessment framework of Bloom's Taxonomy. Student outcomes are therefore not an appropriate tool for assessing cognitive abilities, as they do not provide correct information value. The academic achievement says more about the student's current readiness in the given subject (Berková \& Krpálek, 2017). This is also proven by international research (Kiliyanni \& Sivaraman, 2016; Little, Miyashita, Karasawa, Mashima, Oettingen, Azuma, \& Baltes, 2003) that has shown that students with higher academic achievement can not often think deeper, search for relations, structure, and put it together as opposed to those students whose academic achievement is weak. Thus, the correlation between cognitive dimensions of lower and higher order is weak.

Acquirement of higher cognitive levels can be best demonstrated on the basis of problembased learning, tasks or practical activities. Zoller (2015) has developed a conceptual model of Higher-Order Cognitive Skills (HOCS) for the development of creative thinking that reflects higher order thinking operations. It uses several suitable indicators experimentally verified in secondary and tertiary education: (a) problem solving; (b) the transfer of experience, beliefs of students through learning experience; (c) problem-based questions; (d) decision-making tasks with the support of assessment, moral and creative thinking. The HOCS model is applicable to different levels of education.

Similar research (Freeman, Eddy, McDonough, Smith, Okoroafor, Jordt \& Wenderoth, 2014) was carried out at a university within technical disciplines testing the differences between students who solved tasks based on active information processing. The scores of students taught 
Kateřina BERKOVÁ, Jana BORŮVKOVÁ, Lenka LÍZALOVÁ. Recognition of indicators for the development of the cognitive dimensions in tertiary education

\author{
PROBLEMS \\ OF EDUCATION \\ IN THE $21^{\text {st }}$ CENTURY \\ Vol. 76, No. 6, 2018 \\ 766 by using active learning were 1.5 times higher than those who were taught in a traditional way. \\ According to Buli and Yesuf (2015), the trend of supporting cognitive dimensions of higher \\ order not only in economic but also in technical education has been rising.
}

\title{
Methodology of Research
}

\section{General Background}

Research was empirical, quantitative. This means that the data obtained can be summed up for the conditions under consideration. Research hypotheses are established for verification. The research focuses on comparing the development of cognitive according to Bloom's Taxonomy (Bloom, 1956) up to the level of Evaluation in the students of the economic and technical study field of the college. The research was conducted in 2018 from February to May at the College of Polytechnics Jihlava in the Czech Republic, in the conditions of a practically oriented college, which offers students work experience during studies. Methodological research is based on several international studies on the development of problem-solving thinking (Lamb, Vallet, \& Annetta, 2014; Siew \& Chin, 2018). Siew \& Chin (2018) discuss models of learning and teaching with a different historical and material context that is focused on the timeless Constructivist Learning Theory since 1952 (eg Piaget, 1952; Vygotsky, 1978). These models are based on learning theory based on problem solving and creative thinking development, and are relevant to this research.

The research was based on a test method that obtained data to determine the impact of variables (field of study, academic achievement, abstract visual intellectual level) on the development of the cognitive dimensions according to Bloom's Taxonomy.

\section{Sample}

The sample was created by nonprobability sampling technique. The selection was conditioned by the realization of education in conditions of a practically oriented polytechnictype of college in the Czech Republic. Thus, it was a selection of such a type of higher education institution, which offers more different fields of study and which has common fundamental economic subjects in the study programmes. In the Czech Republic there are only 2 schools of a similar type - in the Vysočina Region and in the South Bohemian Region. For this research, Vysočina Region was selected, given that the researchers knew very well the conditions of education of the mentioned school - the College of Polytechnics in Jihlava, because they have been working as educators there. At the international level, the education has been more practically oriented for longer period of time; study programmes include trends from the application sphere, which are reflected in direct teaching, as published in the study, for example, on practical training on the principles of New Taylorism, Teacher Au (2011). This educational platform is becoming very popular round the world and today it also penetrates into the Czech Republic across various tertiary education study programmes. That is why researchers consider the choice of the college to be relevant as it increases the credibility of the results of research, which is placed in the wider context of practical education in the conditions of technical and economic study fields.

The research, which took place in the academic year 2017/2018, involved students of the economic field Finance and Management $(N=52)$ and students of the Applied Computer Science $(N=30)$. They were students of the first year of studies who completed an economic subject for the fist time. The sampling was intentional. Selected students were the ones without prior study of economic subjects at secondary schools. The phenomenon, when students from non-economic secondary schools are coming to the College of Polytechnics in Jihlava, is very 
Kateřina BERKOVÁ, Jana BORŮVKOVÁ, Lenka LÍZALOVÁ. Recognition of indicators for the development of the cognitive dimensions in tertiary education

common, and therefore this research could have been carried out. The research sample was a total number of students who finished a non-economic secondary school and at the same time completed the subject Corporate Economy in the academic year 2017/2018 under the terms of the College of Polytechnics. Considering age, students were included in the range of 19 to 20 years old.The research sample was divided into two independent samples, to which statistical methods for data analysis were adopted. Overall, the research sample were 82 respondents (Table 1). The selection of these two fields of study was intentional as well in the view of targeting the research. That is, to find differences or concordances in the development of cognitive dimensions of students of the economic field of Finance and Management and the technical field of Applied Informatics.

Table 1. Characteristics of respondents in relation to the field of study.

\begin{tabular}{|c|c|c|c|c|c|c|}
\hline \multirow{2}{*}{ Field of Study } & \multicolumn{2}{|c|}{$\begin{array}{l}\text { Gender } \\
\text { (absolute frequency) }\end{array}$} & \multicolumn{2}{|c|}{$\begin{array}{l}\text { Intelectual Level (absolute } \\
\text { frequency) }\end{array}$} & \multirow{2}{*}{$\begin{array}{l}\text { Acad. } \\
\text { Achiev. in } \\
\text { Corporate } \\
\text { Economy } \\
(\%)\end{array}$} & \multirow{2}{*}{$\begin{array}{l}\text { Achiev. in } \\
\text { Cognitive } \\
\text { Dimensions } \\
(\%)\end{array}$} \\
\hline & Man & Woman & $\begin{array}{l}\text { Above- } \\
\text { average } \\
\text { intelligent }\end{array}$ & $\begin{array}{l}\text { Average } \\
\text { intelligent }\end{array}$ & & \\
\hline $\begin{array}{l}\text { Technical (Applied Com- } \\
\text { puter Science) }\end{array}$ & 27 & 3 & 15 & 15 & 84.48 & 42.79 \\
\hline $\begin{array}{l}\text { Ekonomic (Finance and } \\
\text { Management) }\end{array}$ & 15 & 37 & 27 & 25 & 74.19 & 53.82 \\
\hline Total & 42 & 40 & 42 & 40 & $x$ & $x$ \\
\hline
\end{tabular}

The overall structure of the sample on behalf of students according to intellectual level and gender is almost even, which the researchers consider as representative features.

Intelligence is understood in this research in accordance with the cognitive-contextual definition of Sternberg (2005) as “(1) the ability to achieve one's goals in life, given one's sociocultural context; (2) by capitalizing on strengths and correcting or compensating for weaknesses; (3) in order to adapt to, shape, and select environments; (4) through a combination of analytical, creative, and practical abilities" (Sternberg 2005, p. 189). The IQ value was determined according to standards in the attached tables in the handbook considering age (for the purposes of this research the age was up to 20). In the research, the focus was on abstract visual intelligence, which can be described in these zones, which represent proband standards from the age of 17 up to about 40 (Forman, 2002):

- over 125 - highly above average,

$-110-125$ - above average,

$-91-109$ - average,

- 75 - 90 - below average,

- under 75 - highly below average.

For ethical considerations of the research, each respondent expressed his written consent to the use of the acquired data.

\section{Descriptive Research}

This research was conducted in four phases.

Analysis of educational content of Corporate Economy and assessment of the subject

\begin{tabular}{l} 
PROBLEMS \\
OF EDUCATION \\
IN THE 21 $1^{\text {st }}$ CENTURY \\
Vol. 76, No. 6, 2018 \\
\hline 767
\end{tabular} 
Kateřina BERKOVÁ, Jana BORŮVKOVÁ, Lenka LÍZALOVÁ. Recognition of indicators for the development of the cognitive dimensions in tertiary education

PROBLEMS

OF EDUCATION

IN THE $21^{\text {st }}$ CENTURY Vol. 76, No. 6, 2018

The purpose of this phase was to analyze the educational content of the subject Corporate Economy in both fields of study taking into account Bloom's Taxonomy of cognitive domains (Bloom, 1956). The subject Corporate Economy is studied in the Bachelor's studies in both study fields in the first term as well as it is focused on basic topics relating to the business administration in both fields of study. Students' achievement in the subject is derived from the complexity of the topics that fill the educational content. The course is taught by traditional teaching methods developing mainly cognitive levels of the lower order - Knowledge, Comprehension, Application (Bloom, 1956). Final test was conducted in the Moodle environment and consisted of two examples of (a) calculating depreciation, and (b) compiling the balance sheet, and further (c) a series of closed test questions on the Legal Forms of Business Entity and Property and Capital Development of Business Entity. Academic achievement in Corporate Economy only showed whether students were able to pass the subject on the basis of content presented in one term. It did not show complex economic skills of the students. The reason for the research came out of this fact and that was to find out in which cognitive dimensions students were successful in terms of evaluation using the Bloom's Taxonomy (Bloom, 1956). The research tried to prove whether students could be successful in higher cognitive dimensions, provided they were weaker in cognitive levels of the lower order and vice versa.

Design of learning objectives and model of the problem-based process

Two tests were used to verify hypotheses. The first, standardized Vienna Test System (Forman 2002) found the abstract visual intelligence. The test was chosen in cooperation with the specialized Tescentrum in the Czech Republic which received the research goal and intent. The content validity and reliability of this test has been guaranteed by research conducted since 1993 (Forman, 2002). The administration of the test and its evaluation was provided by psychologists. The test allows to quantify the general level of intellectual power in the level of thinking. The time limit for the test is a maximum of 25 minutes. "The test consists of 24 items, which are arranged with increasing difficulty. Each task contains a $3 \times 3$ image matrix with the missing picture in the third row. The task is to complement the matrix by selecting one of the eight solutions offered. The core of the solution is to discover a rule that determines the relation between the images in each row, respectively. columns. The test contains several types of rules that need to be applied correctly. Creating a rule consists in revealing and understanding the interrelations among the elements, finding and deriving the relevant solution. The overall strategy uses perceptions, thinking, attention, and short-term memory" (Forman, 2002, p. 8).

The second, non-standardized expert test was designed to cover all six cognitive dimensions of Bloom's Taxonomy (Bloom, 1956). This test looked at students' performance in individual cognitive dimensions. Dimension Knowledge was represented by an assignment and a question with an open answer to define a concept. Dimension Comprehension included an assignment with a graphical representation of the Break Even Point, in which it was necessary to read the required numbers, for example, what profit the firm would achieve at a certain volume of production. In the Application dimension, having described situation of an entity in the course of a business year and the data from its initial and final balance sheets, the assignment was to find out how some balance sheet items changed. These three dimensions include lower order thinking processes (Bloom, 1956; Salomon, 1996).

Dimension Analysis was designed to distinguish between activities that had an impact on the net income and to be able to quantify individual items of Expenses, Revenue and Profit and Loss. Dimension Synthesis consisted of assessing the values of the entity indicators presented in the spider chart and their comparison with the industry average. The example on dimension Evaluation showed whether students were able to recognize risks from the business balance sheet and some additional information about the value of the company's working capital, out 
Kateřina BERKOVÁ, Jana BORU゚VKOVÁ, Lenka LÍZALOVÁ. Recognition of indicators for the development of the cognitive dimensions in tertiary education

of which they had to select relevant data, and to provide recommendations for dealing with the imminent crisis situation. These dimensions include higher order thinking operations (Bloom, 1956; Salomon, 1996).

Tasks reflected the problem-solving process. In the proposed model (Table 2), the ability to solve the problem is gradually being developed. The nature of the task enabled students to define the problem - to clarify what they already knew about the problem, analyzing the problem more deeply to find its core. They formulated the hypothesis - the goals and questions leading to solving the problem, what they were going to do and what they had to find out. Subsequently, they performed the analysis in the phase of generating and sorting possible solutions. Cognitive level Evaluation is important for determining the risks and recommendations and other necessary facts in relation to the problem being solved. It has the character of decision-making and implementation in new or modified conditions.

Table 2. A Model of problem-based learning and cognitive dimension in the Bloom's taxonomy.

\begin{tabular}{|c|c|c|}
\hline Cognitive dimension & Contents of curriculum & Logical reasoning \\
\hline Knowledge & $\begin{array}{l}\text { Property and Capital Development of Busi- } \\
\text { ness Entity - terms, definitions. } \\
\text { Business Entity Financing - principles. }\end{array}$ & \multirow{2}{*}{$\begin{array}{l}\text { definition of the problem; } \\
\text { generating possible solutions; } \\
\text { sorting possible solutions. } \\
\text { definition of the problem; } \\
\text { problem analysis; } \\
\text { generating possible solutions; } \\
\text { sorting possible solutions. }\end{array}$} \\
\hline Comprehension & Break Even Point and its interpretation. & \\
\hline Application & $\begin{array}{l}\text { Information functions of the balance sheet } \\
\text { in specific business conditions. }\end{array}$ & $\begin{array}{l}\text { definition of the problem; } \\
\text { problem analysis = hypothesis formulation; } \\
\text { generating possible solutions; } \\
\text { sorting possible solutions. }\end{array}$ \\
\hline Analysis & $\begin{array}{l}\text { Expenses, Revenues, Profit and Loss - } \\
\text { their quantification in terms of production. }\end{array}$ & $\begin{array}{l}\text { definition of the problem; } \\
\text { problem analysis = hypothesis formulation; } \\
\text { generating possible solutions; } \\
\text { sorting possible solutions. }\end{array}$ \\
\hline Synthesis & $\begin{array}{l}\text { Business indicators and their comparison } \\
\text { with the industry average - spider chart. }\end{array}$ & $\begin{array}{l}\text { definition of the problem; } \\
\text { problem analysis = hypothesis formulation; } \\
\text { generating possible solutions; } \\
\text { sorting possible solutions; } \\
\text { evaluation of the best solution. }\end{array}$ \\
\hline Evaluation & $\begin{array}{l}\text { Economic situation of the company, risk } \\
\text { assessment and recommendations. Sub } \\
\text { topics - Balance Sheet, value of working } \\
\text { capital. }\end{array}$ & $\begin{array}{l}\text { definition of the problem; } \\
\text { problem analysis = hypothesis formulation; } \\
\text { generating possible solutions; } \\
\text { sorting possible solutions; } \\
\text { evaluation of the best risk-based solution; } \\
\text { decision making under modified conditions } \\
\text { as recommended. }\end{array}$ \\
\hline
\end{tabular}

Source: Researchers' modifications based on Anderson and Krathwohl (2001); Plamínek (2008); Škoda, Doulík, Bílek and Šimonová (2016). 
Kateřina BERKOVÁ, Jana BORU゚VKOVÁ, Lenka LÍZALOVÁ. Recognition of indicators for the development of the cognitive dimensions in tertiary education

IN THE $21^{\text {st }}$ CENTURY Vol. 76, No. 6, 2018

770 Distribution of research tools for data collection

Between February and May 2018, data were collected through the distribution of research tools among students. Both tests were identical for both study fields. The intellectual level test was administered according to the instructions of the Testcenter (professional psychological workplace in the Czech Republic) and the duration was 25 minutes. The administration of the IQ test and its entire course was conducted by psychologists. Everything was done correctly according to expert instructions. These experts were also examiners who evaluated the results of the IQ test. The distribution of research tools was conducted in such a way as to prevent leaking information among students. Similarly, the administration of both tests was conducted.

Evaluation

To maintain the correctness of the research, data were subsequently assigned to each respondent. Thus, it was possible to analyze the influence of researched factors on the development of cognitive dimensions in the fields but also within the field. Due to the larger number of variables, data reduction was performed through exploration factor analysis, specifically at six cognitive dimensions under Bloom's Taxonomy. Generally speaking, factor analysis from many variables can select those that are statistically related. In case of this research, factor analysis was instrumental in associating cognitive dimensions into two factors. Using the factor analysis it was possible to find out which cognitive dimensions were most related to each other, i.e. whether students could be successful even in higher cognitive dimensions, provided they were weaker in cognitive levels of lower order and vice versa (Kiliyanni \& Sivaraman, 2016; Little, Miyashita, Karasawa, Mashima, Oettingen, Azuma, \& Baltes, 2003; Marzano \& Kendall, 2007).

\section{Data Analysis and Testing of Dependency}

Categorical variables enter into the analyses: field of study and quantitative variables: (a) abstract visual intellectual level (b) academic achievement in Corporate Economy, which was consistent for both fields of study in terms of range and difficulty (c) performance at cognitive dimensions according to Bloom's Taxonomy.

For numerical variables descriptive statistics was calculated using mean, median, standard deviation, minimum, maximum and range, and the normality of these variables was verified using the Shapiro-Wilk and Kolmogorov-Smirnov tests.

Connection within the structure of cognitive dimensions of Bloom's Taxonomy was analyzed by using factor analysis. To determine the correlation between numerical variables, the Spearman correlation coefficient and the Pearson correlation coefficient were calculated. In all cases, the results of both correlation coefficients were similar. Null hypotheses were formulated as follows:

- $\quad$ The field of study does not affect the development of cognitive dimensions according to Bloom's Taxonomy in Corporate Economy.

- $\quad$ Performance in cognitive dimensions according to Bloom's Taxonomy does not correlate with academic achievement in Corporate Economy.

- Abstract visual intellectual level of students does not correlate with the performance in cognitive dimensions according to Bloom's Taxonomy in Corporate Economy.

\section{Results of Research}

The table below shows the measures of location (mean, median) and measures of dispersion (standard deviations, range) for individual cognitive dimensions based on success inthe test (Table 3). 
Kateřina BERKOVÁ, Jana BORŮVKOVÁ, Lenka LÍZALOVÁ. Recognition of indicators for the development of the cognitive dimensions in tertiary education

Table 3. Measures of location and measures of dispersion.

\begin{tabular}{lcccccc}
\hline Cognitive dimension & Mean & Median & Std. Deviation & Minimum & Maximum & Range \\
\hline Knowledge & .73 & .71 & .14 & .36 & 1.00 & .64 \\
\hline Comprehension & .63 & .67 & .23 & .00 & 1.00 & 1.00 \\
\hline Application & .53 & .60 & .31 & .00 & 1.00 & 1.00 \\
\hline Analysis & .60 & .69 & .22 & .00 & 1.00 & 1.00 \\
\hline Synthesis & .52 & .38 & .38 & .00 & 1.00 & 1.00 \\
\hline Evaluation & .20 & .20 & .14 & .00 & .60 & .60 \\
\hline
\end{tabular}

The original Knowledge, Comprehension, Application, Analysis, Synthesis, and Evaluation variables did not have the same weight because the maximum draw points were set for different variables differently. Therefore, the variables were standardized and factor analysis was used for relative success (in per cent). Based on the results of the descriptive statistics, the highest success rate in the cognitive dimension Knowledge was recorded, which relatively reached the value of .73, the lowest success rate was detected for the Evaluation dimension, namely .20. Success in cognitive dimensions, however, did not have a downward trend, which might mean that individual cognitive levels were not mutually conditioned. Thus, that success in higher cognitive levels (i.e. Analysis, Synthesis, Evaluation) was conditioned by success at lower cognitive levels (i.e. Knowledge, Comprehension, Application). The results of descriptive statistics indicated this fact only, but of course they did not confirm it. Therefore, a factor analysis was further selected for this research.

\section{Exploratory Factor Analysis}

The sample was first assessed for its suitability for factor analysis. Bartlett's Test of Sphericity was highly significant $(p<.001)$ and the Kaiser-Meyer-Olkin $($ KMO) measure of sampling adequacy value of .67 supported the factorability of the matrix. Principal Components Analysis (PCA) revealed two eigenvalues exceeding 1, explaining $34.3 \%$ and $18.7 \%$ of the variance respectively. Inspection of the screeplot also supported a two factor solution. Following Varimax with Kaiser Normalization rotation the two factors showed not an intercorrelation $(r$ $<.001$ ). Inspection of the pattern matrix (Table 4) showed a relatively clear two-factor solution. Using this analysis, cognitive dimensions were grouped into two independent factors $(r$ $<.001)$.

Table 4. Pattern matrix for PCA using varimax with kaiser normalization rotation of two factor solution.

\begin{tabular}{lll}
\hline Cognitive & Factor & \\
\cline { 2 - 3 } Dimension & $1-$ Application-Evaluation dimension & 2 - Analytic dimension \\
\hline Evaluation & .747 & - \\
\hline Comprehesion & .702 & - \\
\hline Application & .659 & - \\
\hline Synthesis & - & .727 \\
\hline Analysis & - & .699 \\
\hline Knowledge & - & .653 \\
\hline
\end{tabular}


Kateřina BERKOVÁ, Jana BORU゚VKOVÁ, Lenka LÍZALOVÁ. Recognition of indicators for the development of the cognitive dimensions in tertiary education

OF EDUCAT

IN THE $21^{\text {st }}$ CENTURY Vol. 76, No. 6, 2018

772

Each factor explains exactly the three cognitive dimensions that are conditioned (Table 4). The table shows the correlation between the factor and the relevant cognitive dimension. The higher the correlation, the more this factor is saturated (the correlation must be higher than .3, which is met). These factors, given the cognitive dimensions, can be named as follows: Application-Evaluation Dimension (Factor 1) and Analytical Dimension (Factor 2). The first factor is represented by the dimensions of Application, Comprehension, Evaluation. This means that students cognitively oriented in this way will be able to solve tasks very well when using comprehension, application and evaluation. The second factor is represented by the dimensions of Knowledge, Analysis, Synthesis. Students with this cognitive orientation will be successful in tasks using their knowledge, analysis and synthesis.

Bloom's Taxonomy respects the logical hierarchy in the development of individual cognitive dimensions (Bloom, 1956). It is necessary for students to develop a previous cognitive dimension for the next cognitive shift. On the other hand, each individual is not able to successfully complete the process of learning and problem solving across all cognitive dimensions (Kiliyanni \& Sivaraman, 2016). The results of the research showed that in each factor there was a cognitive dimension of lower and higher order, which did not deny the logic of Bloom's Taxonomy. This research shows that the cognitive process in students can be oriented in two directions: in the application-evaluation line or in the analytical line.

It was further analyzed which cognitive dimensions, or factor 1 or factor 2 were students burdened by considering their field of study (Figure 1).

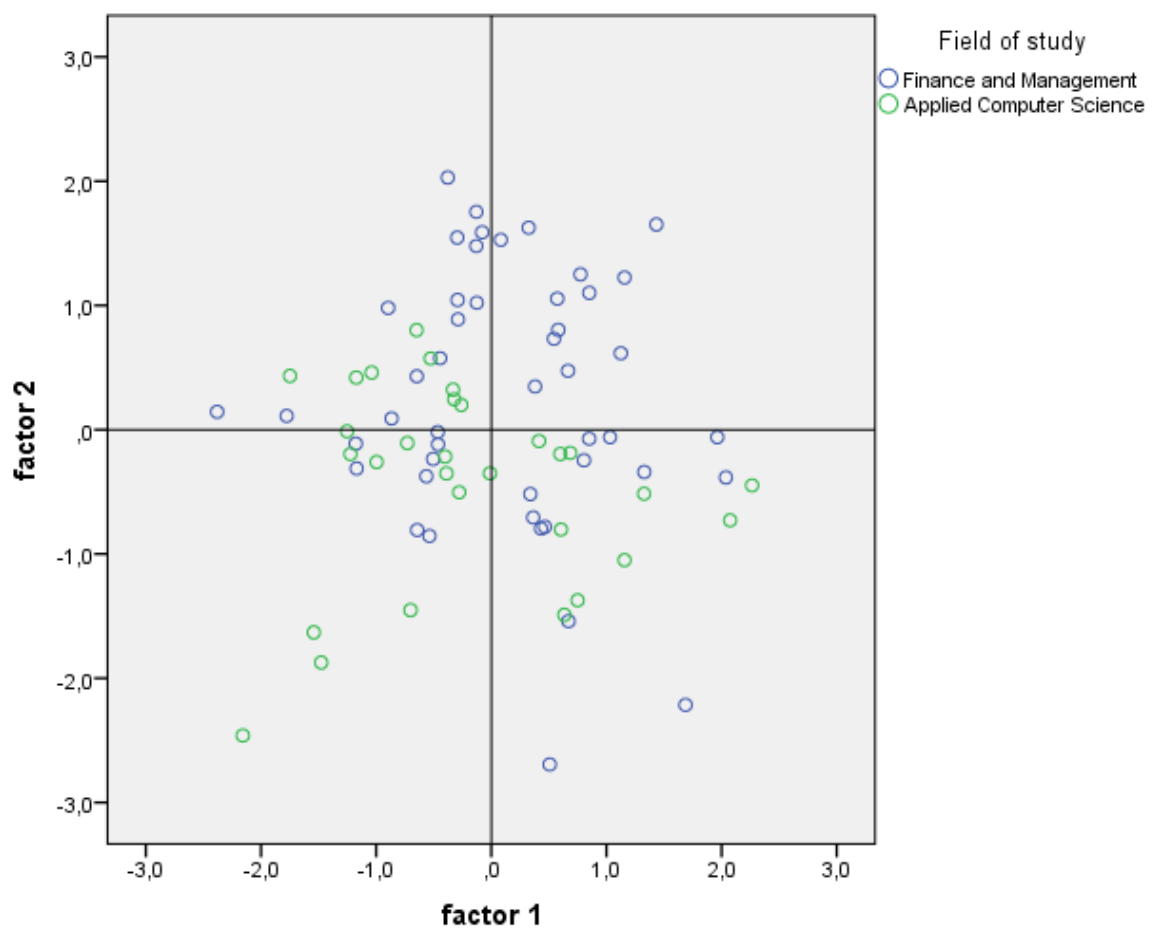

Figure 1. Factor analysis of respondents from the point of view of the field of study.

Students of the economic study field Finance and Management $(N=52)$ are more burdened with factor 2, that is they incline to analytical dimension, compared to students in Applied Computer Science $(N=30)$. Technical students are more burdened with factor 1 - so they incline to application-evaluation dimension. 
Kateřina BERKOVÁ, Jana BORŮVKOVÁ, Lenka LÍZALOVÁ. Recognition of indicators for the development of the cognitive dimensions in tertiary education

At the 5\% level of significance, the researchers reject the null hypothesis: The field of

PROBLEMS

OF EDUCATION

IN THE $21^{\text {st }}$ CENTURY

Vol. 76, No. 6, 2018

study does not affect the development of cognitive dimensions according to Bloom's Taxonomy in Corporate Economy.

At the level of the research sample and in the conditions of a practically oriented college, this means that the field of study affects the development of cognitive dimensions. Students of the economic study field are oriented to the analytical line, which corresponds to the profile and focus of the study field on finance and business management. Students in the field of Applied Informatics are oriented to the application and evaluation line. Despite these results, it is necessary to respect the logical hierarchy of Bloom's taxonomy (Bloom, 1956) and to honor the development of lower cognitive dimensions and the development of higher cognitive dimensions. The research results respect this principle, as each factor is explained by the cognitive dimensions of the lower and higher order. However, the results indicate which cognitive dimensions are dominant in each field of study and which dimensions which students can be successful in.

\section{Analysis of the Relation between Quantitative Variables}

First data normality was tested. According to the S-W test, only the variable Academic Achievement from Corporate Economy does not have a normal distribution (Table 5). Therefore, a Spearman's correlation coefficient was used. The Pearson correlation coefficient was used for all other variables. In most cases, both correlation coefficients are similar.

Table 5. Tests of normality.

\begin{tabular}{lllllll}
\hline \multirow{2}{*}{ Variables } & \multicolumn{3}{l}{ Kolmogorov-Smirnov $^{\mathbf{a}}$} & \multicolumn{4}{l}{ Shapiro-Wilk } \\
\cline { 2 - 7 } IQ value & Statistic & $\boldsymbol{d f}$ & $\boldsymbol{p}$ & Statistic & $\boldsymbol{d f}$ & $\boldsymbol{p}$ \\
\cline { 2 - 7 } Achievement in Corporate & .111 & 70 & .034 & .971 & 70 & .109 \\
Economy & .107 & 70 & .045 & .943 & 70 & .003 \\
Factor 1 & .084 & 70 & $.200^{*}$ & .988 & 70 & .733 \\
Factor 2 & .089 & 70 & $.200^{*}$ & .976 & 70 & .206 \\
\hline
\end{tabular}

* This is a lower bound of the true significance.

a. Lilliefors Significance Correction

Furthermore, the correlation between quantitative variables was researched. These were: (a) academic achievement in Corporate Economy, (b) abstract visual intellectual level, (c) performance in cognitive dimensions in the structure of factor 1 Application-Evaluation Dimension and factor 2 Analytical-Dimension

Table 6. Correlations - Spearman's rho, correlation coefficient.

\begin{tabular}{lllll}
\hline Variables & Factor 1 & Factor 2 & IQ value & $\begin{array}{l}\text { Achievement in } \\
\text { Corporate }\end{array}$ \\
\hline Factor 1 & 1.000 & -.030 & .209 & .208 \\
Factor 2 & -.030 & 1.000 & .147 & $-.266^{*}$ \\
IQ value & .209 & .147 & 1.000 & .189 \\
Achievement in Corporate Economy & .208 & $-.266^{*}$ & .189 & 1.000 \\
\hline
\end{tabular}

*. Correlation is significant at the .05 level (2-tailed). 
Kateřina BERKOVÁ, Jana BORU゚VKOVÁ, Lenka LÍZALOVÁ. Recognition of indicators for the development of the cognitive dimensions in tertiary education

PROBLEMS

OF EDUCATION

IN THE $21^{\text {st }}$ CENTURY

Vol. 76, No. 6, 2018

774

Table 7. Correlations - Pearson correlation.

\begin{tabular}{lllll}
\hline Variables & Factor 1 & Factor 2 & IQ value & Achievement in Corporate \\
\hline Factor 1 & 1.000 & .000 & .177 & .164 \\
Factor 2 & .000 & 1.000 & .161 & $-.301^{*}$ \\
IQ value & .177 & .161 & 1.000 & .127 \\
Achievement in Corporate & .164 & $-.301^{*}$ & .127 & 1.000 \\
Economy &
\end{tabular}

*. Correlation is significant at the .05 level (2-tailed).

The analysis revealed that the variable academic achievement from the subject Corporate Economy correlated weakly negatively $(r=-.301)$ with factor 2, which was represented by the following dimensions: Knowledge, Analysis, Synthesis. Those students who were successful in the development of cognitive dimensions of lower order had a weak analytical orientation in the economic area, while students whose performance in lower-order dimensions was weak had stronger analytical capabilities. Correlation of performance in the test of the subject Corporate Economy with factor 1 - Application-Evaluation Dimension was not proven $(r=.164)$. Factor 1 was represented by the following dimensions: Comprehension, Application, Evaluation.

At the $5 \%$ level of significance, the researchers reject the null hypothesis: Performance in cognitive dimensions according to Bloom's Taxonomy does not correlate with academic achievement in the subject Corporate Economy for the following cognitive dimensions Comprehension, Analysis, Synthesis. The proven correlation is negative, i.e. students with low academic achievement at the level of lower cognitive dimensions have more developed analytical skills, represented by the following partial dimensions: Comprehension, Analysis, Synthesis. Students with higher academic achievements have less developed analytical skills.

The abstract visual intellectual level is not in correlation with any variable.

At the $5 \%$ level of significance, the researchers do not reject the null hypothesis: The abstract visual intellectual level does not correlate with the performance in cognitive dimensions according to Bloom's Taxonomy in Corporate Economy. That means that this type of intelligence is not an important variable in the development of cognitive dimensions in the given economic issues in both fields of study.

\section{Discussion}

The research of indicators of the development of cognitive dimensions in students of a practically oriented college of economic and technical fields has revealed several important facts, which need to be approached in a matter of fact and relations need to be explained with some caution since the research was put into the conditions of a practically oriented college using a research sample $(N=82)$. The following research hypotheses were tested:

- The field of study does not affect the development of cognitive dimensions according to Bloom's Taxonomy in the subject Corporate Economy. Accept. For both fields of study, it was the same subject in terms of educational content, range and difficulty. The students of both fields of study were equally aged between 19 and 20 and had not studied economically oriented secondary schools. Thus, their initial knowledge from the point of view of economic issues was balanced.

- Academic achievement in Corporate Economy correlates with the performance of students in cognitive dimensions according to Bloom's Taxonomy. Accept.

- Abstract visual intellectual level correlates with the performance of students in cognitive dimensions according to Bloom's Taxonomy in Corporate Economy. 
Reject. This type of intellectual level is not related to the development of cognitive dimensions according to the Bloom's Taxonomy. Abstract thinking, working memory, perception or visualization of students do not affect the development of cognitive dimensions of lower and higher order.

It was found that the cognitive dimensions according to Bloom's Taxonomy can be grouped into two factors, each factor containing exactly three dimensions. This demonstrates that degrees of cognitive processes are ranked with increasing complexity in Bloom's Taxonomy but are not cumulative (Bloom, 1956; Langer, 2016).

The first factor is represented by these cognitive dimensions: Application, Comprehension, Evaluation. This means that students of this type of cognitive orientation will be able to solve tasks very well in the situations where they use understanding, application and evaluation, but they will not succeed in other cognitive dimensions. Students of the Applied Computer Science field of study are burdened by factor 1 as well. The application-evaluation reasoning should be mainly developed with these students. This is in line with the international research (Buli \& Yesuf, 2015). This can be achieved by an active way of learning, as confirmed by Freeman, Eddy, McDonough, Smith, Okoroafor, Jordt and Wenderoth (2014).

The second factor is represented by the dimensions of Knowledge, Analysis, Synthesis. The result can be interpreted as follows: Students with this type of cognitive orientation will be successful in tasks where they will use knowledge, analysis and synthesis. Students of the economic field Finance and Management are burdened by factor 2. In 2015, a similar perception was found in the Indonesian college environment saying that students of economic fields could develop cognitive levels of higher order with elements of critical thinking (Subroto, 2015).

However, this research does not question the logical Bloom's Taxonomy (Bloom, 1956). This is proven by the fact that in each factor there is a cognitive dimension of the lower and higher order included. But, at the same time, every individual is not capable in the complexity of Bloom's Taxonomy, which is also confirmed by international research (Kiliyanni \& Sivaraman, 2016, Little, Miyashita, Karasawa, Mashima, Oettingen, Azuma, \& Baltes, 2003). This research shows similar principles that the cognitive process can be oriented in two directions: on the application-evaluation line or on the analytical line.

It was further confirmed that the development of the cognitive dimensions was influenced by students' study fields. Specific educational content on which the development of cognitive levels was realized played an important role too. This was in line with the Zoller's (2015) research that explored cognitive levels in the context of reviewing educational content. The subject Corporate Economy was used for the research and it was designed at a basic level but it was as well suitable for solving problem-based tasks. For the learning process it means that it is necessary to focus on ways of logical reasoning (Broks, 2016; Dasgupta \& David, 1994).

Only factor 2 - Analytical Dimension, which is represented by the following cognitive dimensions (Knowledge, Analysis, Synthesis), correlates with the achievement of students in the subject Corporate Economy. Slightly negative correlation of variables means that students with higher result in the school test in Corporate Economy, which was focused only on the cognitive dimensions of the lower order, were less successful in tasks that reflected the dimensions included in factor 2 and vice versa. This proves that academic achievement reflects more the student's current knowledge in the given subject (Berková \& Krpálek, 2017). In other words that students with higher academic achievement cannot often think more deeply, look for relations, structures, and put them in one complex as opposed to those students whose performance at school is weak (Little, Miyashita, Karasawa, Mashima, Oettingen, Azuma, \& Baltes, 2003; Kiliyanni \& Sivaraman, 2016). The reason may be the predominant style of learning that develops only the cognitive dimension of mechanical acquiring of information and its reproduction (Taylor \& Klein, 1998). This may mean that achievement in the subject Corporate Economy is not given by the real abilities of students, but rather by their attitude to

PROBLEMS
OF EDUCATION
IN THE 21 $21^{\text {st }}$ CENTURY
Vol. 76, No. 6, 2018 
Kateřina BERKOVÁ, Jana BORU゚VKOVÁ, Lenka LÍZALOVÁ. Recognition of indicators for the development of the cognitive dimensions in tertiary education

\author{
PROBLEMS \\ OF EDUCATION \\ IN THE $21^{\text {st }}$ CENTURY \\ Vol. 76, No. 6, 2018 \\ 776 study and by motivation to graduate (Berková, Krejčová, Králová, Krpálek, Krpálková Krelová, \\ \& Koláŕová, 2018).
}

Factor 1 - The Application Evaluation Dimension which is represented by the dimensions Application, Comprehension, Evaluation is not significantly correlated with the academic achievement in the subject Corporate Economy. This may be related to the fact that students in the technical field, who dominate in other cognitive dimensions, are burdened with factor 1.

The development of cognitive dimensions is not correlated with the abstract visual intellectual level. On the other hand, there is research that proves the opposite. The higher-order cognitive levels can be better developed at above average intelligent students who focus on mastery goals (Sternberg \& Williams, 2010). This group of students is able to penetrate deeper into the information and to keep on the top of things over solving problems (Al-Baddareen, Ghaith, \& Akour, 2015). However, this finding has not been proven in this research since it has been oriented on other intellectual level.

\title{
Conclusions
}

The research was focused on finding out about the connection of academic achievement, study field and abstract visual intellectual level with the development of the cognitive dimensions in Bloom's Taxonomy (Bloom, 1956). In education, it is necessary to solve the problem of assessing students' achievement. Not always the academic evaluation corresponds to the real cognitive abilities of students. Therefore, this research problem has been dealt with on an empirical basis.

This research was conducted in the context of economic and technical education. Since students of practically oriented college have the subject Corporate Economy in the study programme of technical field, as well as students of the economic field, this subject was chosen in order to make a comparison. In subsequent period of time the research sample will be extended and the research will be repeated because it was the initial research in a college environment. However, there is still a problem of evaluating students' academic achievement. Students who were successful in the development of lower-order cognitive dimensions had a weak analytical orientation in economic terms and vice versa. That is another research issue that needs to be addressed to in the future. The results brought by the research will help improve teaching of economic subjects across the two disciplines, especially with regard to the innovation of learning and teaching strategies with a positive impact on the desired cognitive development of students.

\section{Acknowledgements}

This research was supported by the College of Polytechnics, Jihlava, Czech under Grant No. 1170/4/181 "Model of Permeability of Corporate Economy and Financial Accounting in the Quality Improving System of the College of Polytechnics Jihlava".

\section{References}

Al-Baddareen, Ghaith, S., \& Akour, M. (2015). Self-efficacy, achievement goals and metacognition as predicators of academic motivation. Procedia Social and Behavioral Sciences, 19, 2068-2073

Anderson, L. W., \& Kratwohl, P. (2001). A taxonomy for learning, teaching a assesing of educational objectives. New York: Longman.

$\mathrm{Au}, \mathrm{W}$. (2011). Teaching under the new Taylorism: High-stakes testing and the standardization of the 21(st) century curriculum. Journal of Curriculum Studies, 43 (1), 25-45. 
Kateřina BERKOVÁ, Jana BORU゚VKOVÁ, Lenka LÍZALOVÁ. Recognition of indicators for the development of the cognitive dimensions in tertiary education

Banchi, H., \& Bell, R. (2008). The many levels of inquiry. Science and Children, 46 (2), 26-29.

Barrett, E., \& Moore, S. (2012). An introduction to problem-based learning. In Barret, E., \& Moore, S.

PROBLEMS

OF EDUCATION

IN THE $21^{\text {st }}$ CENTURY

Vol. 76, No. 6,2018

(Eds.), New approaches to problem-based learning: Revitalizing your practice in higher education (pp. 3-17). New York: Routledge.

Berková, K., \& Krpálek, P. (2017). Approaches to the development of cognitive process dimensions in financial literacy: an empirical study. Journal of International Studies, 10 (3), 173-188.

Berková, K., Krejčová, K., Králová, A., Krpálek, P., Krpálková Krelová, K., \& Kolářová, D. (2018). The conceptual four-sector model of development of the cognitive process dimensions in abstract visual thinking. Problems of Education in the 21st Century, 76 (2), 121-139.

Broks, A. (2016). Systems theory of systems thinking: General and particular within modern science and technology education. Journal of Baltic Science Education, 15 (4), 408-410.

Bloom, B. S. (1956). Taxonomy of educational objectives: The classification of educational goals. New York: McKay.

Buli, B. M., \& Yesuf, W. M. (2015). Determinants of entrepreneurial intentions technical-vocational education and training students in Ethiopia. Education and Training, 57 (8-9), 891-907.

Cetin-Dindar, A. (2012). The effect of $5 E$ learning cycle model on eleventh grade students' conceptual understanding of acids and bases concepts and motivation to learn chemistry (Unpublished dissertation). Ankara: Middle East Technical University.

Crowe, A., Dirks, C., \& Wenderoth, M. P. (2008). Biology in Bloom: Implementing Bloom's taxonomy to enhance student learning in biology. CBE - Life Sciences Education, 7, 368-381.

Dasgupta, P., \& David, P. (1994). Toward a new economics of science. Research Policy, 23 (5), 487-521.

Forman, A. K. (2002). Videňský maticový test [Vienna test system]. Prague: Testcentrum.

Freeman, S., Eddy, S. L., McDonough, M., Smith, M. K., Okoroafor, N., Jordt, H., \& Wenderoth, M. P. (2014). Active learning increases student performance in science, engineering, and mathematics. Proceedings of the National Academy of Sciences of the United States of America, 111 (23), 84108415.

Jurečka, V., Hon, M., Jánošíková, I., Kolcunová, E., \& Spáčilová, L. (2013). Mikroekonomie [Microeconomics]. Prague: Grada Publishing.

Kiliyanni, A. L., \& Sunitha, S. (2016). The perception-reality gap in financial literacy: Evidence from the most literate state in India. International Review of Economics Education, 23, 47-64.

Koenig, J. A. (2011). Assessing 21st century skills. Washington: National Academies Press.

Lamb, R. L., Vallett, D., \& Annetta, L. (2014). Development of a short-form measure of science and technology self-efficacy using rasch analysis. Journal of Science Education and Technology, 23 (5), 641-657.

Langer, T. (2016). Metafory a analogie v ekonomické vědě a vzdělávání [Metaphors and analogies in economics and economic education]. Prague: University of Economics Prague.

Little, TD., Miyashita, T., Karasawa, M., Mashima, M., Oettingen, G., Azuma, H., \& Baltes, P.B. (2003). The links among action-control beliefs, intellective skill, and school performance in Japanese, US, and German school children. International Journal of Behavioral Development, 27 (1), 41-48.

Loužek, M. (2016). The economic approach to science. Prague Economic Paper, 25 (4), 494-506.

Peirce, C. S. (1967). Note on the theory of the economy of research. Operations Research, 15 (4), $643-$ 648.

Salomon, G. (1996). Unorthodox thoughts on the nature and mission of contemporary educational psychology. Educational Psychology Review, 8 (4), 397-417.

Siew, N. M., \& Chin, M. K. (2018). Design, development and evaluation of a problem-based with cooperative module on scientific creativity of pre-schoolers. Journal of Baltic Science Education, 17 (2), 215-228.

Steelová, J. L., Meredith, K. S., Temple, Ch., \& Walter, S. (1997). Co je kritické myšlení (vymezení pojmu a rámce $E-U-R$ ) [What is critical thinking (defining the concept and framework of $\mathrm{E}-\mathrm{R}-\mathrm{R}$ )]. Prague: Kritické myšlení.

Sternberg, J., \& Williams, W. (2010) Educational psychology. New Jersey: Pearson.

Sternberg, R. J. (2005). The theory of successful intelligence. Revista interamericana de Psicología/ Interamerican. Journal of Psychology, 39 (2), 189-202.

Subroto, W. T. (2015). Creative thinking development to foster economic creative: Evidence of state university of Surabaya. International Review of Management and Marketing, 5 (3), 108-113. 
Kateřina BERKOVÁ, Jana BORU゚VKOVÁ, Lenka LÍZALOVÁ. Recognition of indicators for the development of the cognitive dimensions in tertiary education

OF EDUCATION

IN THE $21^{\text {st }}$ CENTURY Vol. 76, No. 6, 2018

Škoda, J., Doulík, P., Bílek, M., \& Šimonová, I. (2016). Learning style as a factor influencing the effectiveness of the inquiry-based science education at lower secondary schools. Journal of Baltic Science Education, 15 (5), 588-601.

OECD (2014). PISA 2012 Results: Students and money. Financial literacy skills for the 21st century (Volume VI). PISA: OECD Publishing. Retrieved 10/08/2001, from: http://www.oecd.org/pisa/ keyfindings/PISA-2012-results-volume-vi.pdf/.

OECD (2017). PISA 2015 Results: Collaboration problem solving (Volume V). Paris: PISA, OECD Publishing. Retrieved 05/12/2017, from: http://dx.doi.org/10.1787/9789264285521-en.

Plamínek, J. (2008). Řešení problémů a rozhodování [Problem solving and decision making]. Prague: Grada Publishing.

Piaget, J. (1952). The origins of intelligence in children. New York: International Universities Press.

Vygotsky, L. S. (1978). Mind in society: The development of higher psychological processes. Cambridge, MA: Harvard University Press.

Zoller, U. (2015). Research-based transformative science/STEM/STES/STESEP education for "sustainability thinking": From teaching to "know" to learning to "think". Sustainability, 7 (4), 4474-4491.

Received: September 07, 2018

Accepted: November 22, 2018

\begin{tabular}{|ll|} 
Kateřina Berková & $\begin{array}{l}\text { Ph.D., Assistant Professor at Department of Economic Studies, College of Polytech- } \\
\text { nics Jihlava, Tolstého 16, Jihlava, } 586 \text { 01, Czech Republic. } \\
\text { E-mail: katerina.berkova@vspj.cz }\end{array}$ \\
\hline Jana Borůvková & $\begin{array}{l}\text { Ph.D., Vice-rector for Study, College of Polytechnics Jihlava, Tolstého 16, Jihlava, } 586 \\
\text { 01, Czech Republic. } \\
\text { E-mail: boruvkova@vspj.cz }\end{array}$ \\
\hline Lenka Lízalová & $\begin{array}{l}\text { Ph.D., Assistant Professor at Department of Economic Studies, College of Polytech- } \\
\text { nics Jihlava, Tolstého 16, Jihlava, 586 01, Czech Republic. } \\
\text { E-mail: lizalova@vspj.cz }\end{array}$
\end{tabular}

